\title{
Effect of acetylsalicylic acid on thalassemia with pulmonary arterial hypertension
}

This article was published in the following Dove Press journal:

International Journal of General Medicine

3 December 2014

Number of times this article has been viewed

\section{Nonlawan \\ Chueamuangphan ${ }^{1,2}$ \\ Wattana Wongtheptian ${ }^{2}$ \\ Jayanton Patumanond ${ }^{3}$ \\ Apichard Sukonthasarn ${ }^{4}$ \\ Suporn Chuncharunee ${ }^{5}$ Chamaiporn Tawichasri ${ }^{6}$ Weerasak Nawarawong ${ }^{4}$ \\ 'Clinical Epidemiology Program, Faculty of Medicine, Chiang Mai University, Chiang Mai, Thailand; ${ }^{2}$ Department of Medicine, Chiang Rai Hospital, Chiang Rai, Thailand; ${ }^{3}$ Clinical Epidemiology Program, Faculty of Medicine, Thammasat University, Bangkok, Thailand; ${ }^{4}$ Department of Medicine, Faculty of Medicine, Chiang Mai University, Chiang Mai, Thailand; ${ }^{5}$ Department of Medicine, Faculty of Medicine, Ramathibodi Hospital, Mahidol University, Bangkok, Thailand; ${ }^{6}$ Clinical Epidemiology Society at Chiang Mai, Chiang Mai, Thailand}

Correspondence: Nonlawan Chueamuangphan Department of Medicine, Chiang Rai Hospital, Chiang Rai 57000, Thailand

Tel +6653 7II 300

Fax +6653713044

Email nonlawanbim@gmail.com
Objective: To compare pulmonary artery systolic pressure (PASP) between thalassemic patients with pulmonary arterial hypertension (PAH) for whom acetylsalicylic acid (ASA) was and was not prescribed after 1 year.

Methods: A retrospective cohort study was conducted at the hematological outpatient clinic at Chiang Rai Hospital, Chiang Rai, Thailand. All new cases of thalassemia with PAH from January 2007 to January 2012 were studied at the first month and at 12 months. The patients were classified into two groups. In one group, ASA $81 \mathrm{mg}$ daily was prescribed for 1 year, whereas in another group no ASA was prescribed, due to its contraindications, which included bleeding, gastrointestinal side effects, and thrombocytopenia. PASP, estimated by a Doppler echocardiography, was measured by the same cardiologist. Propensity score adjustment was used to control confounding variables by indication and contraindication. Multivariable regression analysis was used to evaluate the effects of ASA.

Results: Of the 63 thalassemia patients with PAH, there were 47 (74.6\%) in the ASA group and $16(25.4 \%)$ in the no ASA group. ASA, as compared with no ASA, did not significantly reduce PASP (adjusted difference $-0.95 ; 95 \%$ confidence interval -16.99 to $15.10 ; P=0.906$ ).

Conclusion: Low-dose ASA may not have a beneficial effect on PASP after 1 year of treatment of PAH in thalassemia.

Keywords: thalassemia, pulmonary arterial hypertension, acetylsalicylic acid

\section{Introduction}

Pulmonary arterial hypertension (PAH) is a cardiovascular complication that causes death in thalassemic patients. PAH in thalassemia was reported with a high incidence in several studies. ${ }^{1-4}$ There was evidence that PAH in thalassemia is associated with platelet activation. ${ }^{5-7}$ Acetylsalicylic acid (ASA) lowers the thromboxane-prostaglandin $\mathrm{I}_{2}\left(\mathrm{Tx}-\mathrm{PGI}_{2}\right)$ ratio in $\mathrm{PAH}$ and inhibits platelet activity. ${ }^{8} \mathrm{~A}$ previous cohort study found that the rise of arterial partial pressure of oxygen $\left(\mathrm{PaO}_{2}\right)$ in ten out of the $12 \beta$-thalassemic patients after ASA ten grains or persantin administration for 2-4 weeks indicates that the observed hypoxemia is due to reversible platelet aggregation. ${ }^{9}$ A recent study showed that ASA decreased pulmonary artery pressure, reduced right ventricular hypertrophy, and improved survival in the monocrotaline animal model of PAH. ${ }^{10}$ The erythrocytes and platelets of thalassemic patients contained higher levels of reactive oxygen and lower levels of intracellular glutathione than normal erythrocytes and platelets ${ }^{11}$ that play a role in oxidative stress, thereby leading to the proper therapy.

The standard medication for PAH in thalassemia is not well understood. The mechanism of action of the drugs for PAH is not known. Studies of antiplatelet therapy 
are required before there are conclusive treatment guidelines for thalassemic patients with PAH. In clinical practice, ASA has been used to prevent and treat PAH in thalassemia in Thailand. There were few studies of ASA or antiplatelet therapy in these cases. The aim of the research was to compare after 1 year of follow-up the pulmonary artery systolic pressure (PASP) of patients with thalassemia and $\mathrm{PAH}$ to whom ASA was and was not prescribed.

\section{Materials and methods}

A retrospective cohort study was conducted at the hematological outpatient clinic at Chiang Rai Hospital, Chiang Rai, Thailand. All new adult (aged $\geq 15$ years) cases of thalassemia with PAH defined as PASP $>35 \mathrm{mmHg}$ by Doppler echocardiography (echo) from January 2007 to January 2012 were evaluated and followed from the first month to 12 months later. The patients were classified into two groups. In one group, ASA $81 \mathrm{mg}$ was prescribed daily for 1 year, and in another group, no ASA was prescribed, due to contraindications for ASA (including bleeding, gastrointestinal side effects, and thrombocytopenia [platelets $\left.<100 \times 10^{3} / \mu \mathrm{L}\right]$ ). The physician evaluated drug compliance and side effects. PASP, functional class status, clinical right heart failure, and oxygen saturation were measured at baseline and at the end of 12 months. The functional class status was defined by the New York Heart Association (NYHA) classification. ${ }^{12}$ Patients with other causes of PAH or who used other antiplatelets and/or anticoagulants were excluded. The study protocol was approved by the Institutional Research Ethics Committee and was carried out in accordance with the Declaration of Helsinki.

\section{Echo procedure}

Echo was done by the same cardiologist and the patients' history was blinded. Complete two-dimensional, M-mode, and Doppler (pulsed wave, continuous wave, and color) echo was performed at rest. In the study patients, a tricuspid regurgitation jet was sought from all available midprecordial and apical positions until a flow signal with the maximum spectral representation of the highest velocities was obtained. Peak velocity was recorded from a holosystolic regurgitant jet. From the maximum velocity (V) of the regurgitant jet, the systolic pressure gradient $(\Delta \mathrm{P})$ between the right ventricle and the right atrium was calculated by modified Bernoulli equation $\left(\Delta \mathrm{P}=4 \mathrm{~V}^{2}\right) \cdot{ }^{13}$ Right atrial pressure was estimated by the response of the inferior vena cava diameter to inspiration. Right atrial pressure was assumed to be $5 \mathrm{mmHg}$ if the inferior vena cava completely collapsed with inspiration, $10 \mathrm{mmHg}$ if the inferior vena cava diameter decreased $>50 \%$ during inspiration, and $15 \mathrm{mmHg}$ if it decreased $<50 \%$. If the inferior vena cava diameter was $>2.5 \mathrm{~cm}$ and reduced by $<50 \%$ during inspiration, right atrial pressure was assumed to be $20 \mathrm{mmHg} .{ }^{14}$ Adding the transtricuspid gradient to the mean right atrial pressure provided the right ventricular systolic pressure or peak systolic pulmonary arterial pressure in the absence of right ventricular outflow tract obstruction. PAH was defined as PASP $>35 \mathrm{mmHg} .{ }^{15}$ In cases with an absence of tricuspid regurgitation, at the end of the diastolic pulmonic regurgitant the velocity was calculated using the pressure gradient between the pulmonary artery and right ventricular end diastolic pressure: pulmonary artery pressure $=4(\mathrm{VPR})^{2}+$ right atrial pressure.

\section{Statistical analysis}

The baseline characteristics were compared using exact probability tests for categorical variables; Student's $t$-test or Wilcoxon rank-sum test was used to compare the mean difference of continuous variables. Propensity score adjustment was used to control confounding by ASA indication and contraindication. Propensity scores for prescribing ASA versus no ASA were calculated from a logistic regression model that estimated the likelihood of prescribing ASA based on the observed patient characteristics. Gaussian and an exponential risk regression were carried out. Univariable and multivariable regression analyses were used to evaluate the effects of ASA. Data are presented by frequency, percentage, mean, standard deviation (SD), beta coefficient, 95\% confidence interval $[\mathrm{CI}]$, and $P$-value. All statistical analyses were two-tailed. A $P$-value of $<0.05$ was considered statistically significant.

\section{Results}

A total of 63 thalassemia patients with $\mathrm{PAH}, 53$ with $\mathrm{E} / \beta$-thal, six with homozygous $\beta$-thal, and four with $\mathrm{Hb} \mathrm{H}$ disease were evaluated. There were $47(74.6 \%)$ in the ASA group and $16(25.4 \%)$ in the no ASA group. Patients in the second group had the following contraindications for ASA: seven (43.7\%) bleeding, seven (43.7\%) gastrointestinal side effects, and two $(12.5 \%)$ thrombocytopenia. The mean age was $35.9 \pm 16.8$ years and $28.3 \pm 14.1$ years, and the mean PASP was $51.9 \pm 13.7 \mathrm{mmHg}$ and $45.6 \pm 9.9 \mathrm{mmHg}$ in the ASA group and the no ASA group. The baseline characteristics of the patients did not differ significantly except for red cell transfusion and right ventricular diameter (Table 1). The patients in the ASA group received fewer blood transfusions during the follow-up time of 12 months than those without ASA (6.2 \pm 4.8 vs $11.0 \pm 4.6$ units, $P=0.002)$, and the ASA group 
Table I Baseline characteristics of the patients ${ }^{\mathrm{a}}$

\begin{tabular}{|c|c|c|c|}
\hline Characteristic & $\begin{array}{l}\text { ASA, } \\
n=47\end{array}$ & $\begin{array}{l}\text { No ASA, } \\
n=16\end{array}$ & $P$-value \\
\hline Male (n [\%]) & $16(34.0)$ & $6(37.5)$ & 0.515 \\
\hline Age (years) & $35.9 \pm 16.8$ & $28.3 \pm \mid 4.1$ & 0.112 \\
\hline Weight (kg) & $42.3 \pm 6.2$ & $39.0 \pm 8.3$ & 0.104 \\
\hline Height (cm) & $150.6 \pm 8.2$ & $147.0 \pm 12.1$ & 0.192 \\
\hline \multicolumn{4}{|l|}{ Type of thalassemia (n [\%]) } \\
\hline Hemoglobin & $4 \mathrm{I}(87.2)$ & $12(75.0)$ & 0.288 \\
\hline \multicolumn{4}{|l|}{$E / \beta$-thalassemia } \\
\hline Homozygous & $3(6.4)$ & $3(18.7)$ & \\
\hline \multicolumn{4}{|l|}{$\beta$-thalassemia } \\
\hline Hemoglobin $\mathrm{H}$ disease & $3(6.4)$ & $\mathrm{I}(6.3)$ & \\
\hline Splenectomy (n [\%]) & $29(6 I .7)$ & $13(8 \mid .2)$ & 0.129 \\
\hline $\begin{array}{l}\text { Red cell transfusion } \\
\text { (units/year) }\end{array}$ & $6.2 \pm 4.8$ & $\mathrm{II} \pm 4.6$ & 0.002 \\
\hline $\begin{array}{l}\text { Transfusion dependent } \\
(\geq 9 \text { units/year) ( }[\%])\end{array}$ & $14(29.8)$ & $12(75.0)$ & 0.003 \\
\hline $\begin{array}{l}\text { Nontransfusion } \\
\text { dependent }\end{array}$ & $33(70.2)$ & $4(25.0)$ & \\
\hline \multicolumn{4}{|c|}{ Functional class status: NYHA (n [\%]) } \\
\hline I & $5(10.6)$ & 0 & 0.463 \\
\hline ॥ & $38(80.9)$ & $14(87.5)$ & \\
\hline III & $4(8.5)$ & $2(12.5)$ & \\
\hline $\begin{array}{l}\text { Clinical right heart } \\
\text { failure* }(\mathrm{n}[\%])\end{array}$ & $8(17.0)$ & I (6.3) & 0.270 \\
\hline $\begin{array}{l}\text { Systolic blood } \\
\text { pressure }(\mathrm{mmHg})\end{array}$ & $106.9 \pm 15.0$ & $102.0 \pm 9.2$ & 0.218 \\
\hline $\begin{array}{l}\text { Diastolic blood } \\
\text { pressure }(\mathrm{mmHg})\end{array}$ & $62.6 \pm 8.0$ & $60.5 \pm 6.8$ & 0.352 \\
\hline Pulse rate (/minute) & $85.0 \pm 10.4$ & $90.8 \pm 13.1$ & 0.078 \\
\hline Oxygen saturation (\%) & $95.9 \pm 2.1$ & $96.4 \pm 1.6$ & 0.374 \\
\hline Hemoglobin (g/dL) & $6.3 \pm 0.9$ & $6.3 \pm 0.8$ & 0.903 \\
\hline Corrected & $1 \mathrm{I} .1 \pm 5.8$ & $14.4 \pm 5.7$ & 0.054 \\
\hline \multicolumn{4}{|l|}{ WBCs $\left(\times 10^{3} / \mu \mathrm{L}\right)$} \\
\hline Platelets $\left(\times 10^{3} / \mu \mathrm{L}\right)$ & $369.3 \pm 28.7$ & $50 \mathrm{I} .4 \pm 27.5$ & 0.114 \\
\hline Nucleated & $192.1 \pm 248.4$ & $117.5 \pm 91.0$ & 0.888 \\
\hline \multicolumn{4}{|l|}{$\mathrm{RBCs} / 100 \mathrm{WBCs}$} \\
\hline PT (seconds) & $13.1 \pm 1.2$ & $13.4 \pm 1.0$ & 0.394 \\
\hline PTT (seconds) & $31.2 \pm 3.1$ & $30.7 \pm 3.1$ & 0.560 \\
\hline INR & $1.2 \pm 0.1$ & $1.2 \pm 0.0$ & 0.339 \\
\hline $\begin{array}{l}\text { Aspartate } \\
\text { transaminase (IU/L) }\end{array}$ & $66.5 \pm 48.0$ & $72.0 \pm 48.2$ & 0.540 \\
\hline $\begin{array}{l}\text { Alanine } \\
\text { transaminase (IU/L) }\end{array}$ & $51 \pm 35$ & $52 \pm 37$ & 0.993 \\
\hline Total bilirubin (mg/dL) & $2.7 \pm 1.3$ & $2.6 \pm 1.2$ & $0.78 \mathrm{I}$ \\
\hline HBsAg positive (n [\%]) & $2(4.2)$ & 0 & 0.554 \\
\hline Anti-HCV & $5(10.6)$ & $4(25)$ & 0.157 \\
\hline \multicolumn{4}{|l|}{ positive (n [\%]) } \\
\hline Serum creatinine $(\mathrm{mg} / \mathrm{dL})$ & $0.6 \pm 0.1$ & $0.71 \pm 0.2$ & 0.165 \\
\hline Serum ferritin $(\mu g / L)$ & $3,006 \pm 2797$ & $3,345 \pm 1510$ & 0.067 \\
\hline \multicolumn{4}{|l|}{ Echocardiographic findings } \\
\hline PASP $(\mathrm{mmHg})$ & $51.9 \pm 13.7$ & $45.6 \pm 9.9$ & 0.096 \\
\hline \multicolumn{4}{|l|}{$\begin{array}{l}\text { PASP }(\mathrm{mmHg}) \text { severity } \\
(\mathrm{n}[\%])\end{array}$} \\
\hline $36-50 \mathrm{mmHg}$ (mild) & $25(53.2)$ & $12(75.0)$ & 0.404 \\
\hline $5 \mathrm{I}-70 \mathrm{mmHg}$ (moderate) & $15(31.9)$ & $3(18.7)$ & \\
\hline$>70 \mathrm{mmHg}$ (severe) & $7(14.9)$ & I (6.3) & \\
\hline
\end{tabular}

(Continued)
Table I (Continued)

\begin{tabular}{llll}
\hline Characteristic & $\begin{array}{l}\text { ASA, } \\
\mathbf{n = 4 7}\end{array}$ & $\begin{array}{l}\text { No ASA, } \\
\mathbf{n}=1 \mathbf{6}\end{array}$ & P-value \\
\hline LVEF (\%) & $62.7 \pm 7.8$ & $63.5 \pm 7.4$ & 0.718 \\
LVESd (mm) & $9.5 \pm 2.1$ & $9.0 \pm 2.2$ & 0.445 \\
LVEDd (mm) & $51.5 \pm 6.0$ & $49.4 \pm 7.6$ & 0.256 \\
MPAd (mm) & $25.9 \pm 4.2$ & $25.0 \pm 3.0$ & 0.464 \\
RVd (mm) & $29.5 \pm 5.8$ & $25.5 \pm 4.2$ & 0.016 \\
Poor right ventricular & $7(14.8)$ & 0 & 0.114 \\
systolic function ( $[\%])$ & & & \\
Diastolic function, $\mathrm{n}(\%)$ & & & \\
$\quad$ Mitral valve E:A ratio & $1.4 \pm 0.4$ & $1.2 \pm 0.2$ & 0.515 \\
$\quad$ Mitral valve DT (ms) & $199 \pm 35$ & $202 \pm 88$ & 0.941 \\
Propensity score & $0.8 \pm 0.2$ & $0.2 \pm 0.2$ & $<0.001$ \\
\hline
\end{tabular}

Notes: ${ }^{a}$ alues shown are mean \pm standard deviation unless otherwise specified; *elevated jugular venous pressure, hepatojugular reflux, and edema.

Abbreviations: ASA, acetylsalicylic acid; DT, deceleration time; $\mathrm{E}: \mathrm{A}$, ratio of the early (E) to late $(A)$ ventricular filling velocities; $\mathrm{HBs} A$ g, hepatitis $B$ surface antigen; $\mathrm{HCV}$, hepatitis $C$ virus; INR, international normalized ratio; LVEDd, left ventricular end diastolic diameter; LVEF, left ventricular ejection fraction; LVESd, left ventricular end systolic diameter; MPAd, main pulmonary artery diameter; NYHA, New York Heart Association; PASP, pulmonary artery systolic pressure; PT, prothrombin time; PTT, partial thromboplastin time; RBCs, red blood cells; RVd, right ventricular diameter; WBCs, white blood cells.

had wider right ventricular diameter than the no ASA group (29.5 \pm 5.8 vs $25.5 \pm 4.2 \mathrm{~mm}, P=0.016$ ).

During the follow-up period of 12 months, PASP increased in 12 of 47 (25.5\%) patients in the ASA group and in three of $16(18.7 \%)$ in the no ASA group. Echo findings showed that the patients in the ASA group had a higher mean PASP than the no ASA group, but there was no statistical difference.

After adjusting for propensity score (based on type of thalassemia, splenectomy, $\mathrm{O}_{2}$ saturation, NYHA classification, red cell transfusion, clinical right heart failure, hemoglobin level, platelet count, nucleated red cell, serum ferritin level, baseline PASP, left ventricular ejection fraction, main pulmonary artery diameter, right ventricular diameter, right ventricular systolic function, and diastolic function), there were no statistically significant differences in the functional class status, clinical right heart failure, and oxygen saturation between the two groups (Table 3). ASA, as compared with no ASA, did not significantly reduce PASP (adjusted difference $-0.95 ; 95 \% \mathrm{CI}-16.99$ to $15.10 ; P=0.906$ ). None of the patients had deep vein thrombosis, ischemic stroke and pulmonary embolism.

\section{Discussion}

In the present study, ASA did not improve the functional class status, clinical right heart failure, and oxygen saturation and did not have a significant effect on PASP after 12 months. Both the ASA and the no ASA groups had reduced PASP 
Table 2 Clinical outcomes and echocardiographic findings at 12 months $^{\mathrm{a}}$

\begin{tabular}{|c|c|c|c|}
\hline Outcome & $\begin{array}{l}\text { ASA, } \\
n=47\end{array}$ & $\begin{array}{l}\text { No ASA, } \\
n=16\end{array}$ & $P$-value \\
\hline \multicolumn{4}{|c|}{ Functional class status: NYHA (n [\%]) } \\
\hline I & $5(10.6)$ & I (6.3) & $0.84 I$ \\
\hline ॥ & $39(83.0)$ & $15(93.7)$ & \\
\hline III & $3(6.4)$ & 0 & \\
\hline $\begin{array}{l}\text { Clinical right heart } \\
\text { failure ( } \mathrm{n}[\%])\end{array}$ & $6(12.7)$ & I (6.3) & 0.424 \\
\hline $\mathrm{O}_{2}$ saturation $(\%)$ & $96.7 \pm 2.2$ & $97.1 \pm 1.7$ & 0.492 \\
\hline \multicolumn{4}{|l|}{ Echocardiographic findings } \\
\hline PASP $(\mathrm{mmHg})$ & $47.2 \pm 16.9$ & $41.2 \pm 11.6$ & 0.197 \\
\hline LVEF (\%) & $64.9 \pm 7.5$ & $64.1 \pm 6.4$ & 0.700 \\
\hline LVESd (mm) & $9.6 \pm 2.0$ & $9.8 \pm 2.6$ & 0.759 \\
\hline LVEDd (mm) & $50.6 \pm 5.6$ & $48.7 \pm 6.9$ & 0.266 \\
\hline MPAd (mm) & $25.8 \pm 4.3$ & $24.5 \pm 3.3$ & 0.249 \\
\hline $\operatorname{RVd}(\mathrm{mm})$ & $29.7 \pm 6.2$ & $26.6 \pm 3.0$ & 0.057 \\
\hline $\begin{array}{l}\text { Poor right ventricular } \\
\text { systolic function (n [\%]) }\end{array}$ & $6(12.7)$ & 0 & 0.158 \\
\hline \multicolumn{4}{|l|}{ Diastolic function } \\
\hline Mitral valve E:A ratio & $1.5 \pm 0.5$ & $1.7 \pm 0.9$ & 0.395 \\
\hline Mitral valve DT (ms) & $205 \pm 28$ & $217 \pm 29$ & 0.382 \\
\hline
\end{tabular}

Note: ${ }^{a}$ Values shown are mean \pm standard deviation unless otherwise specified. Abbreviations: ASA, acetylsalicylic acid; DT, deceleration time; E:A, ratio of the early $(E)$ to late $(A)$ ventricular filling velocities; LVEDd, left ventricular end diastolic diameter; LVEF, left ventricular ejection fraction; LVESd, left ventricular end systolic diameter; MPAd, main pulmonary artery diameter; NYHA, New York Heart Association; PASP, pulmonary artery systolic pressure; RVd, right ventricular diameter.

by $-4.7 \pm 11.0 \mathrm{mmHg}$ and $-4.3 \pm 7.1 \mathrm{mmHg}$ with no clinical or statistical significance. The results of this study were similar to those of a randomized clinical trial of ASA and simvastatin for $\mathrm{PAH}$, which concluded that the results did not support the routine treatment of patients with $\mathrm{PAH}$ with these medications. ${ }^{16}$ And thalassemia patients who experienced a thromboembolic event and received ASA afterwards had a lower recurrence of thromboembolic event compared with those who were not taking ASA, although these differences were not statistically significant. ${ }^{17}$ Subgroup analysis of E/ $\beta$-thal; ASA, as compared with no ASA, did not significantly reduce the PASP (adjusted difference -3.62 ; $95 \% \mathrm{CI}-11.84$ to $4.60 ; P=0.225)$. For the transfusion- and nontransfusion-dependent patients, ASA did not significantly change the PASP.

In contrast to the previous study that reported that there was a rise of arterial $\mathrm{PaO}_{2}$ after high-dose ASA administration in thalassemia patients with $\mathrm{PAH},{ }^{9}$ we found that oxygen saturation rose in the patients who had received low-dose ASA but without statistical significance (adjusted difference $0.31 ; 95 \% \mathrm{CI}-1.71$ to $2.33 ; P=0.757)$.

PAH developed in thalassemic patients because of platelet activation and hypercoagulable state. ${ }^{18,19}$ Therefore, it was
Table 3 Effect of acetylsalicylic acid on clinical outcomes and echocardiographic findings

\begin{tabular}{|c|c|c|}
\hline Outcome $^{a}$ & $\begin{array}{l}\text { Adjusted } \\
\text { difference* }(95 \% \mathrm{CI})\end{array}$ & $P$-value \\
\hline Functional class status: & $0.30(-3.18$ to 3.78$)$ & 0.865 \\
\hline \multicolumn{3}{|l|}{ NYHA class (n [\%]) } \\
\hline $\begin{array}{l}\text { Clinical right heart } \\
\text { failure }(\mathrm{n}[\%])^{c}\end{array}$ & -0.001 ( -3.86 to 3.86$)$ & 0.999 \\
\hline $\mathrm{O}_{2}$ saturation $(\%)$ & 0.31 (-I.7I to 2.33$)$ & 0.757 \\
\hline \multicolumn{3}{|l|}{ Echocardiographic findings } \\
\hline PASP $(\mathrm{mmHg})$ & $-0.95(-16.99$ to 15.10$)$ & 0.906 \\
\hline LVEF (\%) & $-0.66(-9.24$ to 7.92$)$ & 0.877 \\
\hline $\operatorname{LVESd}(\mathrm{mm})^{\mathrm{d}}$ & $-0.76(-4.08$ to 2.56$)$ & 0.655 \\
\hline LVEDd (mm) & $-1.47(-8.50$ to 5.56$)$ & 0.673 \\
\hline MPAd (mm) & $1.19(-2.67$ to 5.06$)$ & 0.534 \\
\hline $\operatorname{RVd}(\mathrm{mm})^{\mathrm{d}}$ & $0.83(-4.62$ to 6.29$)$ & 0.765 \\
\hline $\begin{array}{l}\text { Poor right ventricular } \\
\text { systolic function, n (\%) }\end{array}$ & $15.37(-2,2 \mid 9$ to 2,250$)$ & 0.989 \\
\hline \multicolumn{3}{|l|}{ Diastolic function } \\
\hline Mitral valve E:A ratio ${ }^{d}$ & $0.46(-1.78$ to 2.70$)$ & 0.687 \\
\hline Mitral valve DT $(\mathrm{ms})^{d}$ & $-25.62(-47.89$ to -3.36$)$ & 0.024 \\
\hline
\end{tabular}

Notes: *Adjusted for propensity score (type of thalassemia, splenectomy, $\mathrm{O}_{2}$ saturation, NYHA classification, red cell transfusion, clinical right heart failure, hemoglobin level, platelet count, nucleated red cell, serum ferritin level, baseline PASP, LVEF, MPAd, RVd, right ventricular systolic function, and diastolic function). ${ }^{2} G$ Gaussian regression unless otherwise indicated; bordered logistic regression; 'generalized linear models: extensions to the binomial family; 'generalized linear models: Poisson regression.

Abbreviations: $\mathrm{Cl}$, confidence interval; DT, deceleration time; $\mathrm{E}: \mathrm{A}$, ratio of the early $(E)$ to late $(A)$ ventricular filling velocities; LVEF, left ventricular ejection fraction; MPAd, main pulmonary artery diameter; NYHA, New York Heart Association; PASP, pulmonary artery systolic pressure; RVd, right ventricular diameter.

reasonable that antiplatelet therapy alone may be less effective for PAH in thalassemia. Its role in the prevention of PAH in thalassemia should be evaluated.

Further studies of PAH management will be required before conclusive recommendations can be made for antiplatelet or anticoagulant therapy or prevention for high risk of PAH in thalassemia (postsplenectomy status ${ }^{3}$ ).

The present study may have some limitations, as it was not a randomized controlled trial, the duration of treatment was only 12 months, and the 6-minute walk test was not used as a clinical outcome due to its retrospective nature. The lack of cardiac catheterization to confirm PASP is a limitation for a therapeutic trial of $\mathrm{PAH} .{ }^{20}$ However, echo is more sensitive and is a commonly used noninvasive tool to screen PAH. More evidence from observational studies or preferably randomized clinical trials may be required before it can be concluded that ASA would offer any beneficial effects to these patients.

The current therapies for PAH in thalassemia include the use of sildenafil ${ }^{21,22}$ and bosentan. ${ }^{23}$ However, a large cohort of patients on the topic are needed before definite recommendations can be made. 


\section{Conclusion}

The present findings suggested that low-dose ASA may not have a beneficial effect on PASP after 1-year treatment of $\mathrm{PAH}$ in thalassemia.

\section{Acknowledgments}

The authors wish to thank the medical staff members of Chiang Rai Hospital for their assistance and Chiang Mai University for its financial support.

\section{Disclosure}

The research was partially supported by a grant from the Graduate School of Chiang Mai University, Thailand. The authors declare no other conflicts of interest in this work.

\section{References}

1. Du ZD, Roguin N, Milgram E, Saab K, Koren A. Pulmonary hypertension in patients with thalassemia major. Am Heart J. 1997;134(3):532-537.

2. Aessopos A, Farmakis D, Karagiorga M, et al. Cardiac involvement in thalassemia intermedia: a multicenter study. Blood. 2001;97(11): 3411-3416.

3. Phrommintikul A, Sukonthasarn A, Kanjanavanit R, Nawarawong W. Splenectomy: a strong risk factor for pulmonary hypertension in patients with thalassaemia. Heart. 2006;92(10):1467-1472.

4. Sonakul D, Pacharee P, Laohapand T, Fucharoen S, Wasi P. Pulmonary artery obstruction in thalassaemia. Southeast Asian J Trop Med Public Health. 1980;11(4):516-523.

5. Eldor A, Lellouche F, Goldfarb A, Rachmilewitz EA, Maclouf J. In vivo platelet activation in beta-thalassemia major reflected by increased platelet-thromboxane urinary metabolites. Blood. 1991;77(8): 1749-1753.

6. Opartkiattikul N, Funahara Y, Fucharoen S, Talalak P. Increase in spontaneous platelet aggregation in beta-thalassemia/hemoglobin E disease: a consequence of splenectomy. Southeast Asian J Trop Med Public Health. 1993;23 Suppl 2:S36-S41.

7. Atichartakarn V, Angchaisuksiri P, Aryurachai K, Chuncharunee S, Thakkinstian A. In vivo platelet activation and hyperaggregation in hemoglobin E/ $\beta$-thalassemia: a consequence of splenectomy. Int J Hematol. 2003;77(3):299-303.

8. Robbins IM, Kawut SM, Yung D, et al. A study of aspirin and clopidogrel in idiopathic pulmonary arterial hypertension. Eur Respir J. 2006;27(3):578-584.
9. Fucharoen S, Youngchaiyud P, Wasi P. Hypoxaemia and the effect of aspirin in thalassaemia. Southeast Asian J Trop Med Public Health. 1981;12(1):90-93.

10. Shen L, Shen J, Pu J, He B. Aspirin attenuates pulmonary arterial hypertension in rats by reducing plasma 5-hydroxytryptamine levels. Cell Biochem Biophys. 2011;61(1):23-31.

11. Amer J, Fibach E. Oxidative status of platelets in normal and thalassemic blood. Thromb Haemost. 2004;92(5):1052-1059.

12. Rubin LJ; American College of Chest Physicians. Diagnosis and management of pulmonary arterial hypertension: ACCP evidence-based clinical practice guidelines. Chest. 2004:126(Suppl 1):7S-10S.

13. Yock PG, Popp RL. Noninvasive estimation of right ventricular systolic pressure by Doppler ultrasound in patients with tricuspid regurgitation. Circulation. 1984;70(4):657-662.

14. Otto CM. Echocardiographic evaluation of left and right ventricular systolic function. In: Otto CM, editor. Textbook of Clinical Echocardiography. 2nd ed. Philadelphia, PA: WB Saunders; 2000:100-128.

15. Barst RJ, McGoon M, Torbicki A, et al. Diagnosis and differential assessment of pulmonary arterial hypertension. J Am Coll Cardiol. 2004;43(12 Suppl S):40S-47S.

16. Kawut SM, Bagiella E, Lederer DJ, et al. Randomized clinical trial of aspirin and simvastatin for pulmonary arterial hypertension: ASA-STAT. Circulation. 2011;123(25):2985-2993.

17. Taher A, Isma'eel H, Mehio G, et al. Prevalence of thromboembolic events among 8,860 patients with thalassaemia major and intermedia in the Mediterranean area and Iran. Thromb Haemost. 2006;96(4):488-491.

18. Singer ST, Kuypers FA, Styles L, Vichinsky EP, Foote D, Rosenfeld H. Pulmonary hypertension in thalassemia: association with platelet activation and hypercoagulable state. Am J Hematol. 2006;81(9):670-675.

19. Taher AT, Otrock ZK, Uthman I, Cappellini MD. Thalassemia and hypercoagulability. Blood Rev. 2008;22(5):283-292.

20. Janda S, Shahidi N, Gin K, Swiston J. Diagnostic accuracy of echocardiography for pulmonary hypertension: a systematic review and meta-analysis. Heart. 2011;97(8):612-622.

21. Prasertwitayakij N, Sukonthasarn A, Karnjanawanit R, Kuanprasert S, Promminthikul A. Effect of sildenafil on pulmonary artery pressure in thalassemic patients. Thai Heart Journal. 2006;19(2):63-71.

22. Morris CR, Kim HY, Wood J, et al. Sildenafil therapy in thalassemia patients with Doppler-defined risk of pulmonary hypertension. Haematologica. 2013;98(9):1359-1367.

23. Anthi A, Tsangaris I, Hamodraka ES, Lekakis J, Armaganidis A, Orfanos SE. Treatment with bosentan in a patient with thalassemia intermedia and pulmonary arterial hypertension. Blood. 2012;120(7): $1531-1532$
International Journal of General Medicine

\section{Publish your work in this journal}

The International Journal of General Medicine is an international, peer-reviewed open-access journal that focuses on general and internal medicine, pathogenesis, epidemiology, diagnosis, monitoring and treatment protocols. The journal is characterized by the rapid reporting of reviews, original research and clinical studies across all disease areas.

\section{Dovepress}

A key focus is the elucidation of disease processes and management protocols resulting in improved outcomes for the patient. The manuscript management system is completely online and includes a very quick and fair peer-review system. Visit http://www.dovepress.com/ testimonials.php to read real quotes from published authors. 